\title{
Yenidoğan Sepsisinde Çok Nadir Bir Etken: Serratia Liquefaciens
}

\author{
A Very Rare Cause Of Neonatal Sepsis: Serratia Liquefaciens
}

\author{
Ufuk Çakır1, Serdar Alan', Duran Yıldız', Dilek Kahvecioğlu1, Ömer Erdeve1, Begüm \\ Atasay', Ahmet Derya Aysev², Saadet Arsan'1
} 'Ankara Üniversitesi Tıp Fakültesi Cebeci Hastanesi, Cocuk Sağlı̆̆ı̆
ve Hastalıkları Anabilim Dalı, Neonatoloji Bilim Dall, Ankara, Türkiye

${ }^{2}$ Ankara Üniversitesi Tıp Fakültesi Cebeci Hastanesi, Cocuk Sağlı̆̆ ve Hastalıkları Anabilim Dalı, Ankara, Türkiye

\begin{abstract}
Serratialar, fırsatçı gram negatif, aerob bakterilerdir. Bakteriyemi, alt solumum yolları, cerrahi yaralar, deri ile yumușak dokularda enfeksiyonlara yol açmakta ve genel olarak nozokomiyal enfeksiyonların \%2'sinden sorumlu tutulmaktadırlar. Serratia türlerinden insanda enfeksiyon ajanı olarak izole edilen en sık tipi serratiamarcescens (S.marcescens)'dir (\%97). Serratialiquefaciens (S.liquefaciens) insan klinik örneklerinden nadiren izole edilmesine rağmen, ikinci en sık izole edilen Serratia türü olarak düsünülmektedir. S.liquefaciens, serratia türleri içinde ikinci en sık neden iken yenidoğan yoğun bakım ünitelerinde sıklığı bilinmemektedir. Literatürde nadir bildirilen bu patojen yenidoğanlarda ciddi mortalite ve morbidite nedeni olarak gösterilmiștir. Șu ana kadar S.liquefaciensbeș yenidoğanda raporlanmıș olup, menenjiti olan bir olgu kaybedilmiștir.

$3560 \mathrm{~g}$ term bebek solunum sıkıntısı nedeniyle yenidoğan yoğun bakım ünitesine yatırıldı. İki gün solunum destek tedavisi aldı. Postnatal 10. günde akut faz yüksekliğinin ve trombositopeninin eșlik ettiği ateș nedeniyle hastadan kan, beyin omurilik sIVISı ve idrar kültürleri alınarak antibiyotik tedavisi (vankomisin, meropenem) bașlandı. Beș gün boyunca trombosit desteği verilen hastanın kan kültüründe S.liquefaciens üredi. (amikasin, ertapenem, gentamisin, imipenem, piperasilin-tazobaktam, siprofloksasin duyarlı, ampisilin, kolistin, sefalotin, tetrasiklin dirençli). Meropenem tedavisi 14 güne tamamlanan hasta taburcu edildi.

Ünitemizde daha önce sepsis etkeni olarak saptanmayan ve yenidoğanlarda çok nadir bir etken olan S.liquefaciens duyarlı olduğu meropenem ile morbiditesiz olarak tedavi edilmiștir. Bu yazıda, yenidoğanlarda oldukça nadir bir sepsis ajanı S.liquefaciens'ebağlı bir neonatalsepsis olgusu sunularak, bu ajanın literatür eșliğinde tartıșılması amaçlanmıștır.

Anahtar Sözcükler: Yenidoğan, Sepsis, Serratialiquefaciens, Serratia, Trombositopeni

Serratias are opportunistic, gram negative aerobic bacteria. They lead to bactremia lower respiratory tract infections, surgical wound, skin and soft tissue infections, and are responsible from $2 \%$ of nosocomial infections. Serratia marcescens is the most common (97\%) isolated pathogen among Serratia species, while Serratia liquefaciens (S.liquefaciens) is the second most common pathogenic organism with $2 \%$. Its infection frequency in the neonatal intensive care units is not known. This pathogen, which is very rarely reported in the medical literature, shown to be a cause of severe mortality and morbidity in newborns. To the best of our knowledge, up to now only five newborn cases have been reported in the literature, of whom one died due to meningitis.

A - $3560 \mathrm{~g}$ - term infant was admited to our neonatal intensive care unit for respiratory insufficiency and received respiratory support for 2 days. On postnatal 10th day, she presented with fever which was accompanied with elevated acute phase reactants and severe thrombocytopenia. Antibiotic (vancomycin and meropenem) combination was begun after collected cultures from blood, cerebrospinal fluid and urine. She had to receive thrombocyte suspension for 5 days. Blood culture was reported as growth of S.liquefaciens (sensitive to amikacin, ertapenem, gentamicin, imipenem, piperacilin-tazobactam and ciprofloxacin, resistant to ampicillin, colistin, cefalotin and tetracycline). The patient was discharged after completed meropenem treatment for 14 days.

S.liquefaciens was never detected as a causative agent for sepsis in our unit, and it was treated with meropenem therapy successfully without any morbidity. Here, we aimed to report a neonatal sepsis case due to this very rare pathogen, S.liquefaciens, and review the literature.

Key Words: Newborn, Sepsis, Serratialiquefaciens, Serratia, Thrombocytopenia.
\end{abstract}

Serratialar, önceleri Enterobacteriaceae ailesinden olduğu düşünülen, sonra Bacillus türlerinden gen transferi sonras1 türeyip ayr1 bir bakteri ailesi olarak, firsatçı gram negatif, aerob bakterilerdir (1,2). Serratia türleri, Özellikle Serratiamarcescens (S.marcescens) insanlarda ve hayvanlarda önemli bir enfeksiyon ajanıdırlar. Şu ana kadar 14 alt tipi tanımlanmıştır. İlk 1819'da patojen olmayan bakteri olarak tanımlansa da yıllar içerisinde firsatçı enfeksiyon ajanı olarak literatürde yer almıştır (2). S. marcescens, Serratia'lar içinde önemli yeri olan patojenler olmakla birlikte, bu cins içinde nadir 
olarak hastalık yaptığ bildirilen $S$. plymuthica, S. liquefaciens, S. rubidaea ve $S$. odorifera türleri de bulunmaktadır. Bakteriyemi, alt solunum yollar1, cerrahi yaralar, deri ile yumuşak dokularda enfeksiyonlara yol açmakta ve genel olarak nozokomiyal enfeksiyonların $\% 2$ 'sinden sorumlu tutulmaktadırlar. Serratia kaynaklı nozokomiyalenfeksiyonlardamortalite hız1 \%26 oranlarında bildirilmektedir (1).

$\mathrm{Bu}$ yazıda yenidoğan yoğun bakım ünitelerinde geç neonatalsepsis ajanı olarak çok nadir görülen Serratialiquefaciens'e (S.liquefaciens) bağlı bir sepsis olgusu sunulmakta, etkin tedavi ile morbiditesiz iyileşmesi ve daha önce bildirilmemiş eşlik eden ciddi trombositopeni birlikteliği tartışılmaktadır.

\section{OLGU SUNUMU}

Hastamız 26 yaşındaki annenin ikinci gebeliğinden, ikinci yaşayan, 38 hafta 5 günlük sezaryenle $3560 \mathrm{~g}, 1 / 9$ APGAR ile doğdu. Vajinal doğum sirasinda kordon sarkması nedeniyle acil sezaryen doğumla doğan hastanın solunumunun olmaması ve bradikardik olması üzerine pozitif basinçlı ventilasyon uyguland. Bradikardisi devam eden hasta entübe şekilde yenidoğan yoğun bakım ünitesine yatırıldı. Perinatal öyküde annede enfeksiyona ait gösterge yoktu. Solunumsal asidozu olan hasta bir gün mekanik ventilatör ve bir gün sürekli pozitif hava yolu basınç desteği aldı. Tam oral beslenen hastanın postnatal 10. günde kliniğinde bozulma olmaksızın, vücut 1sısı 38,6C $\mathrm{C}^{\circ}$, akut faz yüksekliği (beyaz küre: $15000 / \mathrm{mm}^{3}$, C-reaktif protein: $187 \mathrm{~g} / \mathrm{L}$, immatür/total nötrofil oranı: 0,2$)$ ve trombositopenisi $\left(4000 / \mathrm{mm}^{3}\right)$ olması üzerine geç neonatalsepsis açısından kültürleri alınarak vankomisin (30 mg/kg/gün) ve meropenem (60 $\mathrm{mg} / \mathrm{kg} /$ gün $)$ tedavileri başlandı. Beyin omurilik sivis1 (BOS) ve tam idrar incelemesinde hücre görülmedi; BOS ve idrar kültürlerinde üreme olmadi. Trombositopenisi 5 gün devam ettiği için günlük trombosit desteği aldı. Kan kültüründe S.liquefaciens üreyen ve antibiyograminda meropenem duyarlilığ1 olan (antibiyogramdaamikasin, ertapenem, gentamisin, imipenem, piperasilintazobaktam, siprofloksasin duyarl, ampisilin, kolistin, sefalotin, tetrasiklin dirençli) hastada vankomisin 7. günde, kontrol kan kültüründe üreme olmaması, akut fazlarının normal olması üzerine meropenem tedavisi 14. günde kesildi. Postnatal 13. günde tam orale geçilen hasta postnatal 27. günde taburcu edildi. Hasta postnatal 6. ayda poliklinik düzeyinde morbiditesiz izlenmektedir.

\section{TARTIȘMA}

Burada rapor edilen S.liquefaciens'e bağlı yenidoğansepsisi dişında, literatürde şu ana kadar S.liquefaciens 5 yenidoğanda (3 sepsis, 2 menenjit) raporlanmış olup, menenjiti olan bir olgu kaybedilmiştir. Aynı olgunun otopsisinde S.liquefaciens'e bağlı meningoensefalit ve nekroze beyin dokusuyla karakterize enfeksiyon tanımlanmıştır (2). Ünitemizde daha önce sepsis etkeni olarak saptanmayan ve yenidoğanlarda çok nadir bir etken olan S.liquefaciens duyarlı olduğu meropenem ile morbiditesiz olarak tedavi edildi. Daha önceki klinik çalışmalarda ve antibiyogramlarda da bu patojenin karbapenemlere duyarlılık oranı yüksek olarak bildirilmiştir (1). Sepsis sırasında trombositopenisi için trombosit desteği alan hastamızdaki trombositopeni S.liquefaciens sepsisinde daha önce tanımlanmamıştır.

Serratia türlerinden insanda enfeksiyon ajanı olarak izole edilen en sik tipi S.marcescens'dir. S. Marcescens sağlik hizmeti veren merkezlerde özellikle yenidoğan ünitelerinde ciddi hastane enfeksiyonlarına neden olabilir. Çevredeki yüzeyler, tıbbi cihazlar, intravenöz ya da topikal solüsyonlar ve sağlık çalışanlarının elleri kaynak olabilir (3). S.marcescens, özellikle prematür ve düşük doğum ağırlıklı yenidoğanlar için ölüme sebep olan ciddi bir ajandır (4). $S$. marcescens'e bağlı mortalite \%10-20 arasında bildirilmekle beraber, yenidoğan yoğun bakım ünitesinde sepsis ilişkili genel mortalite \%12 iken,S. marcescens'e bağlı mortalite \%24 olarak bulunmuştur (5). Tiraş ve ark. yenidoğanlardaS. marcescens'e bağlı mortaliteyi \%50 olarak bildirmişlerdir (4). Grimont ve arkadaşları tarafindan hastaneye yatan erişkin 1108 hastanın serratia türleri içerisinde \%97'inde S.marcescens, \%2'sinde ikinci en sik Serratialiquefaciens izole etmişlerdir (6). S.liquefaciens, serratia türleri içinde ikinci en s1k neden iken yenidoğan yoğun bakım ünitelerinde sıklığ1 bilinmemektedir. Literatürde nadir bildirilen bu patojen yenidoğanlarda ciddi mortalite ve morbidite nedeni olarak gösterilmiştir (7).

S.liquefaciens'in hastanede yatan 1108 hastanın $\% 2$ 'sinde izole edildiği bildirilmiştir (6). Erişkinlerde 21 kan kültüründen 15 'inde karışık Serratia türleri ve 6'sında S.liquefaciens üremesi olmuştur. Altı hastanın birinde ölümle sonuçlanan mukopürülan bronşit, diğerlerinde sellülit, gangrenöz ayak ülseri ve pnömonide izole edilmiştir. İdrar yolu enfeksiyonu, beyin cerrahi ve hemodiyaliz ünitelerinde enfeksiyon ajanı olarak bildirilmiştir (2). S. liquefaciens'ler; en sık çocuk yaş grubunda (\%57.1) patojen olduğu ve en sik idrar kültürlerinde (\%42.8) ve ikinci sıklıkta yara kültürlerinde (\%35.7) saptanmıştır (1). Yoğun Bakım yatışı harici bahsedilen risk faktörlerinden hiçbiri hastamızda mevcut değildi.

Sonuç olarak, yenidoğan yoğun bakım ünitelerinde Serratiasepsisinin çok nadir görülmesinin yanısıra S.liquefaciens'e bağlı sepsisliteratürde çok az olguda bildirilmiştir. Etkin tedavi edilemediği durumda ölüme neden olabilen bir mikrororganizma olmasindan dolay1 Serratia tiplerinin dikkate alınması ve uygun antibiyotikle tedavi edilmesi hayat kurtarıcı olacaktır. 


\section{KAYNAKLAR}

1- Bozkurt H, Güdücüoğlu H, Bayram Y, ve ark. Klinik Örneklerden Üretilen Serratia Cinsi Bakterilerin Çeşitli Infeksiyonlardaki Rolü ve Antimikrobiyallere Duyarlılıkları. Van Tip Dergisi: 2005; 12:182-188.

2- Mahlen SD. Serratia infections: from military experiments to current practice. Clin Microbiol Rev. 2011;24:755-791.
3- Bayramoglu G, Buruk K, Dinc U, et al. Investigation of an outbreak of Serratia marcescens in a neonatal intensive care unit. J Microbiol Immunol Infect. 2011;44:111-115.

4- Tiraş Ü, Erdeve Ö, Çamurdan O, et al. Serratia marcescens: A Serious Death Causing Agent for Neonates. T Klin J Med Sci 2002, 22:571-573.

5- Bizzarro MJ, Dembry LM, Baltimore RS, et al. Case-control analysis of endemic Serratia marcescens bacteremia in a neonatal intensive care unit. Arch Dis Child Fetal Neonatal Ed. 2007;92:120126.

6- Grimont, F., and P. A. D. Grimont. In M. Dworkin, et al. The genus Serratia. 3rd ed., vol. 6. Springer Science and Business Media, New York, NY: The prokaryotes; 2006: 219-244.

7- Fitzgerald P, Drew JH, Kruszelnicki I. Serratia: a problem in a neonatal nursery. Aust Paediatr J. 1984;20:205-207. 
